\title{
What Do Mongolian Facebook Users Want from Advertisers?
}

\author{
Massoud Moslehpour ${ }^{1}$, Jargal Tumurbaatar ${ }^{2}$, Khoirul Amri ${ }^{1} \&$ Munkh-Ulzii Batmunkh ${ }^{1}$ \\ ${ }^{1}$ Department of Business Administration, Asia University, Taichung, Taiwan \\ ${ }^{2}$ Sales Account Manager, ACTi Corporation, Taipei, Taiwan \\ Correspondence: Khoirul Amri, Department of Business Administration, Asia University, 500, Lioufeng Rd., \\ Wufeng, Taichung 41354, Taiwan. Tel: 886-909-827-991. E-mail: mrkhoirulamri@gmail.com
}

Received: June 15, 2016

Accepted: July 4, 2016

Online Published: August 10, 2016

doi:10.5539/ijbm.v11n9p51

URL: http://dx.doi.org/10.5539/ijbm.v11n9p51

\begin{abstract}
This study is one of its kinds to explore Mongolian Facebook users' attitudes towards advertising. It uses traditional factors and examines the relationship among the factors to discover the variables with strongest influence among the Mongolian Facebook users. Moreover, researchers included gender as one of the relevant demographic variables as the moderating variable. This study surveyed 400 Mongolian Facebook active users through the online questionnaire. The research findings indicate that informativeness and entertainment followed by credibility are the most influential factors of Facebook users' attitudes towards advertising. In addition, gender moderates the relationship between credibility and attitude towards Facebook advertising. For practical implications, this study helps business marketers who are interested in attracting Mongolian customers within the Facebook advertising program. For social implications, social scientists may find the results useful for their study of human behavior and motivation, and how this information may affect attitudes towards the adoption and attraction of advertisings. This study is limited to Mongolian Facebook users.
\end{abstract}

Keywords: Facebook advertising, Facebook marketing, social media marketing, Attitude toward advertising, Mongolia

\section{Introduction}

\subsection{Definition of Advertising}

Kotler (1988) found that advertising is used to inform, remind, and persuade consumers as well as to strengthened their attitudes and perceptions. The purpose of advertising, according to Kotler (1988) is to attract potential buyers' responses to the organization and its offering, by providing information, supplying reasons and channeling the desire for preferring a particular offer.

Advertising is an important component of marketing and regardless of its swift growth (Shavitt, Lowrey, \& Haefner, 1998) the advertising industry has also been concerned with improving its dull public image (Mittal, 1994). Advertising also plays an important role in informing people about their possible choices of products and services available in the market (Sachiko, 2004). Previous research points out that attitudes towards advertising influence the success of any particular advertising (Friman, 2010).

Krombholz, Merkl, and Weippl (2012) in their study about Facebook as a business model mentioned that Facebook has become a global mass marvel. According to Gross and Acquisti (2006) Facebook as one of the social media is one the fastest developing e-services. The emergence and sophistication of the social media has resulted in growing expectations on precise and efficient communication of retailer's with their customers (Boyd \& Ellison, 2007).

\subsection{Facebook Advertising}

With its 1.65 billion monthly active users (Facebook Newsroom, 2016) Facebook.com is one of the largest social media sites in the world. Facebook is a relatively new social media that helps its members to set up a homepage where they can make friends and share their personal pictures, videos, likes and dislikes with others. In this platform members are allowed to set their preferences, play games, find friends, sell their items other ever growing activities. Moreover, Facebook is a platform for advertisers allowing them to set up their own profile pages at no initial charge. Companies, in return share their customer's information with Facebook about the actions of Facebook members on their sites (Louise, 2007). The booming speed of increasing number of 
Facebook users all around the world have made this site most attractive field for the small, medium and large businesses as an advertising tool.

Learmonth and Klaassen (2009) reported that $43 \%$ of online purchasers decided to make their purchase due to surfing through various social-networks. Social media advertising is a market is relatively a new market, but is projected to produce $\$ 11$ billion in profits by 2017 (Karr, 2014). These numbers show the power that advertisers have to reach their audience (Katherine, 2010). However, to fully understand the effect of Facebook advertising, it is important to understand how consumers attitude toward Facebook and its advertisers.

The aim of this study is to investigate the influences of Informativeness, Entertainment, Credibility and Gender on Mongolian Facebook user's attitude toward Facebook advertising. This study presents findings that are important to both practitioners and scholars. On the applied side, it enhances practitioners understanding of some of the variables that are most influential toward attitudes of Mongolian Facebook users toward Facebook advertising. The results contribute to better understanding of how advertisers can manipulate advertising characteristics of Facebook pages to increase Mongolian user positive attitude towards Facebook advertising. Furthermore, this research is one of the very few scholarly endeavors to investigate Mongolian Facebook user attitude toward Facebook advertising. The results of this study will help both scholars and practitioners to enrich their understanding of social media, and in particular Facebook, advertising.

\subsection{Mongolian Facebook Users}

Mongolia's GDP growth was reported at 2.3\% in 2015 (ADB Report, 2016). In 1994 Mongolian society firstly connected with the worldwide internet access. Since middle of the 2010 the number of Mongolian internet users rapidly increased in Facebook site. In 2010 Mongolian new Facebook users' rate was ranked at second in Asia. According to Facebook Statistics (2016), in the Facebook field Mongolian internet users are growing over 529.080 profiles so far. By this result Mongolia is ranking in the 103th place in the world with $29 \%$ penetration rate in the past 6 months with $48 \%$ male and $52 \%$ female users.

The main purpose of this study is to investigate the Facebook advertising effectiveness by scrutinizing Mongolian users' attitude toward Facebook advertising. This research was designed to answer the following questions:

1) Which factors most affect Mongolian Facebook users' attitude toward Facebook Advertising?

2) Does gender moderate the relationship between Independent Variables (IV) and Dependent Variable (DV)?

\section{Literature Review}

\subsection{Definition of the Constructs}

\subsubsection{Attitude toward Advertising}

Attitude toward Advertising (Hereinafter referred to as ATT): In this study is defined as "a learned predisposition to respond in a consistently favorable or unfavorable manner toward advertising in general" (Lutz, 1985, p.53). Attitudes are also defined as learned tendencies to react with certain consistency to any given situation and have been studied as the dependent variable in several studies (Eze \& Lee, 2012; Hanna \& Wozniak, 2001; Petty \& Cacioppo, 1981; Wei \& Long, 2015). According to Okoe and Boateng (2015) consumers' attitude determines their willingness to accept mobile advertising. In addition, customers' attitudes toward mobile social media advertising can turn positively influence brand attitude. And, the brand attitude positively influences behavioral intentions. However, according to Aydin (2016) overall attitudes are negative towards both the mobile app advertisements and Facebook advertisements. ALsamydai, Yousif, and Al-Qirem (2013) study aims to measure the individuals' attitude towards Arabic speaking TV news channels (Aljazeera, Al-Arabiya, BBC, CBC and Al-Hurra) as well as the impact of these channels on the current events. The study indicates that these channels influence individuals' attitudes as well as the current events.

\subsubsection{Informativeness}

Informativeness (Hereinafter referred to as INF): in the context of this study, Informativeness can be defined as "the ability of advertising to inform consumers of product alternatives so that purchases yielding the greatest possible satisfaction can be made" (Ducoffe, 1996, p. 21). Informativeness is the ability to inform customer about possible available variety of a product or service (Gao \& Koufaris, 2006). Informativeness of the ad has a positive and significant influence on attitudes towards Facebook advertising (Ashmawy, 2014). Similar, Informative is significantly related to consumers' attitude towards online advertising (Lee, Loo, Peng, \& Xian, 2015). In addition, Informativeness of Social Network Sites' Advertisements (SNSAs) has a positive effect on social network sites advertisements' value (SNSAV), as perceived by social network sites (SNS) users (Deraz, 
Awuah, \& Gebrekidan, 2015). According to Wei and Long (2015), there is a significant positive relationship between Informativeness and attitude toward (Mobile Social Media) MSM advertising. On this basis, we propose the following hypothesis:

H1: Informativeness has statistically significant influence on the attitude towards Facebook advertising.

\subsubsection{Entertainment}

Entertainment (Hereinafter referred to as ENT): Entertainment is "the ability to fulfill an audience's needs for escapism, diversion, aesthetic enjoyment or emotional enjoyment" (McQuail, 1983, p. 176). Entertainment element in advertising can fulfill consumers' needs for aesthetic enjoyment and emotional release (Ducoffe, 1996). Bauer and Greyser (1968), Pollay and Mittal (1993) found that Entertainment had a positive effect on the attitude towards advertising. Entertainment refers to the ability to arouse aesthetic enjoyment ( $\mathrm{Oh} \& \mathrm{Xu}, 2003)$. Entertainment of an ad has a significant positive relationship with attitude towards Facebook advertising (Ashmawy, 2014). In addition, Entertainment value of Social Network Sites' Advertisements (SNSAs) has a positive effect on social network sites advertisements' value (SNSAV), as perceived by social network sites (SNS) users (Deraz, Awuah, \& Gebrekidan, 2015). According to Aydin (2016), Entertainment factor appeared as the most important factor affecting attitudes towards Digital Advertisements (Social Media Ads and Mobile Ads). Moreover, in another study found that the Entertainment value of advertisement affects consumers' attitudes toward mobile advertising significantly (Okoe \& Boateng, 2015). Similar, Entertainment factor appeared as the most important factor affecting attitudes towards Digital Advertisements (Social Media Ads and Mobile Ads) (Aydin, 2016). On this basis, we propose the following hypothesis:

H2: Entertainment has statistically significant influence on the attitude towards Facebook advertising.

\subsubsection{Credibility}

Credibility (Hereinafter referred to as CRE): Advertising credibility has been defined by Mackenzie and Lutz (1989) as "the extent to which the consumer perceives claims made about the brand in the ad (advertising) to be truthful and believable" (p. 26). Advertising credibility is significantly relevant to advertising value of web advertising (Brackett \& Carr, 2001). Credibility has also been shown to be one of the variables influencing attitudes towards advertising (MacKenzie \& Lutz, 1989; Shavitt, Lowrey, \& Haefner, 1998). Credibility factor is considered as one of the important factors affecting attitudes towards digital advertisements including Social Media Ads and Mobile Ads (Aydin, 2016). Besides, credibility of the ad has a significant positive relationship with attitudes towards Facebook advertising (Ashmawy, 2014). In addition, Credibility value of Social Network Sites' Advertisements (SNSAs) has a positive effect on social network sites advertisements' value (SNSAV), as perceived by social network sites (SNS) users (Deraz, Awuah, \& Gebrekidan, 2015). However, according to Lee, Loo, Peng, and Xian (2015) Credibility is insignificantly related to consumers' attitude towards online advertising. Similar, the relationship between Credibility and Attitude toward Mobile Social Media (MSM) advertising is found to be insignificant (Wei \& Long, 2015). On this basis, we propose the following hypothesis:

H3: Credibility of advertising has statistically significant influence on the attitude towards Facebook advertising.

\subsection{Relevant Demographic Variables}

\subsubsection{Gender}

Rehman, Ilyas, Nawaz, and Hyder (2014) indicate that Facebook advertisement has positive influence on buying behavior of young consumers. Same study indicates that Gender has moderating influence on Facebook advertisement attitude. Eisend, Plagemann, and Sollwedel (2014) studied the gender role in advertising. Their study indicates that there are significant differences between male and female in the way that women and men are tagetted in advertising. Furthermore, they point that men are more likely to be interested in humorous ads versus women. On this basis, we propose the following hypothesis:

H4: There are significant differences between male and female Facebook users' attitude toward Facebook advertising. 


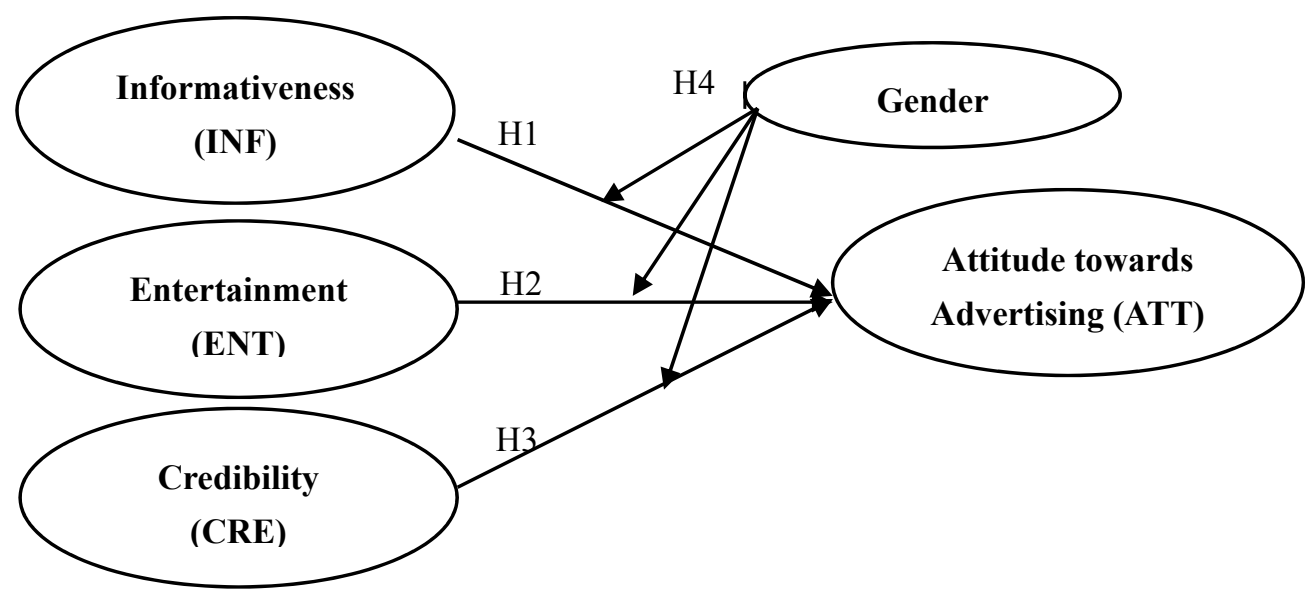

Figure 1. Research model

\section{Methodology}

\subsection{Research Design}

This study uses a quantitative research design, and investigates the relationship among research constructs, using the survey as its method of investigation. We have one dependent variable which is attitude toward advertising in Facebook and there are five independent variables will be used in the research such as Entertainment, Informativeness, and Credibility. In addition, gender as demographic variables.

\subsection{Questionnaire Design}

The questionnaire has comprised of two parts. The first part includes demographic information, with our relevant demographic variables such as gender, age and education. Second part has comprised six sections, each construct has measured by some items adapted from literature review, including Entertainment ( 5 items), Informativeness ( 5 items), Credibility (5 items), and Attitude towards Advertising ( 6 items). All questions are elicited by using a five Likert scale ranging from 1 "strongly disagree" through to 5 "strongly agree".

\subsection{Sampling Technique and Data Collection}

The purpose of this study is to examine the factors affecting Mongolian Facebook users' attitude toward Facebook advertising. Samples of this study were Mongolian Facebook active users. Totally 400 respondents selected randomly to ask their attitude toward advertising through the Facebook site. Questionnaire have distributed conveniently to Mongolian Facebook users by online.

\subsection{Data Analysis Procedure \& Measurement}

The items on each scale were generated on the basis of similar previous measures in the literature and measured on a 5-point Likert-type. At the end of the survey participation period, the results were exported from the private website to an Excel file. The quantitative data was coded and tabulated and imported into SPSS. The Statistical Package and Product Solutions (SPSS) analysis tool was used to obtain the statistical results. Measurement instrument should be both valid and reliable. The reliability of the instrument was verified using Cronbach's alpha. The validity of the instrument was measured by KMO (Kaiser-Meyer-Olkin's Measure of sampling adequacy) (Moore, 1991). Multi regression analysis was used to test the hypotheses.

\subsubsection{Multi Regression Analysis}

The variable $\mathrm{Y}$ is labeled as the outcome or dependent variable. The variables $\mathrm{X}_{1}, \mathrm{X}_{2}, \mathrm{X}_{3}, \mathrm{X}_{4} \ldots \mathrm{X}_{\mathrm{i}}$, are designated as the independent variables or predictors of the study. Multiple regression equation is the mathematical representation of how independent variables explain a proportion of the variance in a dependent variable. The coefficients indicate the magnitude and the direction of the relationship. The constant is the y-intercept (Sosor, 2012).

\section{Results and Findings}

\subsection{Descriptive Statistic Analysis of Sample Demographics}

Four hundred Mongolian Facebook users have participated in the data collection through the Facebook site as a volunteer. 
Table 1. Sample demographics

\begin{tabular}{|c|c|c|c|c|}
\hline No & Characteristics & Categories & Frequency & Percentage $(\%)$ \\
\hline \multirow[t]{5}{*}{1} & Age & less than 19 & 38 & 9.5 \\
\hline & & $20-29$ & 238 & 59.5 \\
\hline & & $30-39$ & 85 & 21.3 \\
\hline & & $40-49$ & 31 & 7.7 \\
\hline & & 50 and more & 8 & 2.0 \\
\hline \multirow[t]{2}{*}{2} & Gender & Male & 164 & 41.0 \\
\hline & & Female & 236 & 59.0 \\
\hline \multirow[t]{2}{*}{3} & Marital status & Married & 188 & 47.0 \\
\hline & & Not married & 212 & 53.0 \\
\hline \multirow[t]{4}{*}{4} & Occupation & Self-employee & 30 & 7.5 \\
\hline & & Student & 138 & 34.5 \\
\hline & & Employee & 214 & 53.5 \\
\hline & & Other & 18 & 4.5 \\
\hline \multirow[t]{4}{*}{5} & Education & Secondary school & 74 & 18.5 \\
\hline & & Bachelor & 196 & 49.0 \\
\hline & & Master & 106 & 26.5 \\
\hline & & Doctoral & 24 & 6.0 \\
\hline \multirow[t]{4}{*}{6} & Location & Capital city & 306 & 76.5 \\
\hline & & Small Town & 37 & 9.3 \\
\hline & & Countryside & 22 & 5.5 \\
\hline & & Other & 35 & 8.8 \\
\hline \multirow[t]{4}{*}{7} & Login place & Home & 252 & 63.0 \\
\hline & & School & 3 & 0.8 \\
\hline & & Work & 117 & 29.3 \\
\hline & & Other & 28 & 7.0 \\
\hline \multirow[t]{4}{*}{8} & Years of usage & less than 6 months & 8 & 2.0 \\
\hline & & 6-11 months & 8 & 2.0 \\
\hline & & $1-2$ years & 93 & 23.3 \\
\hline & & more than 2 years & 291 & 72.7 \\
\hline
\end{tabular}

\subsection{Reliability Test}

The reliability of the measurement tools were assessed by the Cronbach's alpha reliability coefficient. It is proposed to be more than 0.6 and items-to-total correlation of more than 0.3 , but more than 0.5 and items-to-total correlation of more than 0.2 are justifiable with regard to its moderate within a few constructs. As shown in the last column of Table 2 , the reliability coefficients ranged from 0.90 to 0.93 , which was significantly higher than the acceptable level of $(\alpha \geq .6)$. These results confirm that the scales used are all reliable.

Table 2. Reliability assessment of variables

\begin{tabular}{clccc}
\hline No & Variables & Variable Code & $\begin{array}{c}\text { Number of } \\
\text { Questions }\end{array}$ & $\begin{array}{c}\text { Cronbach's Alpha } \\
(\boldsymbol{\alpha})\end{array}$ \\
\hline $\mathbf{1}$ & Informativeness & INF & 5 & 0.90 \\
$\mathbf{2}$ & Entertainment & ENT & 5 & 0.93 \\
$\mathbf{3}$ & Credibility & CRE & 4 & 0.90 \\
$\mathbf{4}$ & Attitude towards advertising & ATT & 4 & 0.91 \\
$\mathbf{5}$ & Total Instrument & & 18 & 0.96 \\
\hline
\end{tabular}

Cronbach's alpha for the dependent variable (Attitude toward advertising) is determined to be 0.91 which is considered as a strong reliability. The reliability for the whole instrument is 0.96 ; also a very strong reliability number for the instrument. Therefore, at this point we have established the reliability of the instrument. Next, we look at the validity of the instrument. 


\subsection{Exploratory Factor Analysis (EFA)}

Exploratory factor analysis (EFA) is an important tool for organizational researchers. It can be useful for refining measures, evaluating construct validity, and in some cases testing hypotheses.

Excluding the demographic measures, a total of 21 measures were used in the data analysis to capture the various latent constructs. All of 3 endogenous variables had good fit in EFA as shown Table 3. Totally three measures were excluded during the EFA rotation because of the bad loadings on other constructs. The deleted items in this section were:

Credibility, item 4:

-If I want to buy a new product, I switch FB ads to get information.

Attitude towards advertising, item 4:

-FB ads reflect a true picture of the product advertised.

Attitude towards advertising, item 5:

-FB ads play an important role in my buying decisions.

Table 3. Rotated component matrix for exploratory factor analysis

\begin{tabular}{|c|c|c|c|c|c|}
\hline & \multicolumn{4}{|c|}{ Components } & \multirow[b]{2}{*}{ Questions } \\
\hline & 1 & 2 & 3 & 4 & \\
\hline INF1 & .78 & & & & FB ads provide the information I need \\
\hline INF2 & .75 & & & & FB ads tell me which brands have the features that I am looking for \\
\hline INF3 & .82 & & & & FB ads offer me the information I need to make (my) purchasing decisions \\
\hline INF4 & .78 & & & & I feel that FB ads are more informative than other advertising media \\
\hline INF5 & .76 & & & & $\begin{array}{l}\text { FB ads keep me up to date about products/ services available in the } \\
\text { marketplace }\end{array}$ \\
\hline ENT1 & & & .80 & & FB ads contain a lot of excitement and surprises \\
\hline ENT2 & & & .83 & & FB ads are more entertaining than other advertising sources \\
\hline ENT3 & & & .79 & & FB ads are amusing \\
\hline ENT4 & & & .78 & & The pictures on FB ads are attractive \\
\hline ENT5 & & & .77 & & Sometimes I take pleasure in thinking about what I saw in FB ads \\
\hline CRE1 & & .72 & & & I trust FB ads \\
\hline CRE2 & & .79 & & & The content provided by FB ads are highly credible \\
\hline CRE3 & & .74 & & & The pictures on FB ads are trustworthy \\
\hline CRE5 & & .55 & & & I use FB ads as a reference for purchasing \\
\hline ATT1 & & & & .76 & I like to receive and read FB ads \\
\hline ATT2 & & & & .77 & I have a positive attitude towards FB ads \\
\hline ATT3 & & & & .82 & FB ads are relevant to my needs \\
\hline ATT6 & & & & .65 & FB ads are pleasing \\
\hline KMO & & & & .926 & \\
\hline \multicolumn{6}{|c|}{ Cumulative (\%) } \\
\hline & & & & 65.455 & \\
\hline P-value & & & & .000 & \\
\hline
\end{tabular}

Extraction Method: Principal Component Analysis.

Rotation Method: Varimax with Kaiser Normalization.

\subsection{Validity Test-Factor Analysis}

Construct validity was explored (Table 4) in order to confirm accuracy and adequacy within the sample, measuring the sample, and measuring the validity of each variable by the rules defined below:

1) Eigen value must be greater than 1.

2) KMO (Kaiser-Meyer-Olkin's Measure of sampling adequacy) is suggested to be more than 0.5.

3) Factor loading with cut point is 0.5 . 


\subsubsection{Informativeness (INF)}

According to result of factor analysis, 5 questions, which measure the Informativeness variable, are higher than 0.5 those ranged from 0.75 to 0.82 . Eigen value for content is 3.62 which indicate compatibility with the Eigen-value-greater-than-one-rule. The cumulative proportion for this variable is $72.41 \%$. For the KMO measure of sampling adequacy, in this analysis the KMO is 0.85 that is an acceptable threshold for the analysis. The chi-square for mobility access was $\chi^{2}=1288.49$, it was significant $(\rho<0.001)$.

\subsubsection{Entertainment (ENT)}

Factor loading are from 0.77 to 0.83 point. The Eigen value of this construct is 3.91 and that is compatible with Eigen-value-greater-than-one-rule. The 78.35 percent of total variance is explained by this factor. Kaiser-Meyer-Olkin measure of sampling adequacy is 0.863 that is an acceptable result. With $\chi^{2}=1642.73$, Bartlett's test of sphericity was significant $(\mathrm{p}<0.001)$.

\subsubsection{Credibility (CRE)}

According to result of factor analysis, one question CRE4, which measures the credibility variable, was arranged in the different column of factor analysis table and has been deleted. Factor loadings are from 0.55 to 0.79 point. Eigen value for content is 3.09 which indicate compatibility with the Eigen-value-greater-than-one-rule. The cumulative proportion for this variable is $77.41 \%$. For the KMO measure of sampling adequacy, in this analysis the $\mathrm{KMO}$ is 0.83 that is an acceptable threshold for the analysis. The chi-square for mobility access was $\chi^{2}=$ 1042.41, it was significant $(\rho<0.001)$.

\subsubsection{Attitude towards Advertising (ATT)}

Measuring this variable not whole factor loadings have valued as useful. ATT4, ATT5 were deleted because of not arranged with other measures of variable Attitude towards advertising. The 4 questions which valued are above 0.5 that altogether ranged between 0.65 and 0.82 . Minding the Eigen-value-greater-than-one-rule, the Eigen value of this construct is 3.14. The cumulative proportion analyzed as 78.60. Furthermore, the Kaiser-Meyer-Olkin measure of sampling adequacy is 0.835 that exceeds the pre-set threshold for factor analysis as 0.6 or above. Bartlett's test of sphericity was significant $\left(\chi^{2}=1129.63, p<0.05\right)$.

Table 4. Factor loading

\begin{tabular}{|c|c|c|c|c|c|c|}
\hline Variable & $\begin{array}{l}\text { Questionnaire } \\
\text { Items }\end{array}$ & $\begin{array}{l}\text { Factor } \\
\text { Loading }\end{array}$ & $\begin{array}{l}\text { Eigen } \\
\text { value }\end{array}$ & $\begin{array}{l}\text { Variance } \\
\text { extraction (\%) }\end{array}$ & KMO & P value \\
\hline Informativeness & INF1 & 0.78 & 3.62 & 72.42 & 0.85 & $0.000 * * *$ \\
\hline \multirow[t]{4}{*}{ (INF) } & INF2 & 0.75 & & & & \\
\hline & INF3 & 0.82 & & & & \\
\hline & INF4 & 0.78 & & & & \\
\hline & INF5 & 0.76 & & & & \\
\hline Entertainment & ENT1 & 0.80 & 3.91 & 78.35 & 0.86 & $0.000 * * *$ \\
\hline \multirow[t]{4}{*}{ (ENT) } & ENT2 & 0.83 & & & & \\
\hline & ENT3 & 0.79 & & & & \\
\hline & ENT4 & 0.78 & & & & \\
\hline & ENT5 & 0.77 & & & & \\
\hline \multirow[t]{4}{*}{ Credibility (CRE) } & CRE1 & 0.72 & 3.09 & 77.41 & 0.83 & $0.000 * *$ \\
\hline & CRE2 & 0.79 & & & & \\
\hline & CRE3 & 0.74 & & & & \\
\hline & CRE5 & 0.55 & & & & \\
\hline Attitude towards & ATT 1 & 0.76 & 3.14 & 78.60 & 0.83 & $0.000 * * *$ \\
\hline \multirow[t]{3}{*}{ advertising (ATT) } & ATT2 & 0.77 & & & & \\
\hline & ATT3 & 0.82 & & & & \\
\hline & ATT6 & 0.65 & & & & \\
\hline
\end{tabular}

\subsection{Multiple Regression Analysis}

Multiple regression is a useful method that finds the independent factors' influence into dependent variable. Multiple regressions are widely used to explore the influence between variables in marketing research. Hypothesis testing is based on the standardized path coefficient (r-path coefficient). To support the hypotheses, 
the p-value of the r-path coefficient should be significant at the 0.001 level. Researchers want to find out the most relevant factors influencing in Facebook users' attitude towards Facebook advertising.

In this study Attitude towards Advertising chosen as the dependent variable. Using multiple regression gives us a better understanding about relationship between independent variables and dependent variable. In order to examine the extent to which factors are influenced with Facebook advertising, linear regression test was run by adding three independent variables and dependent into the SPSS statistical field.

Table 5. Results of multiple regression analysis for male

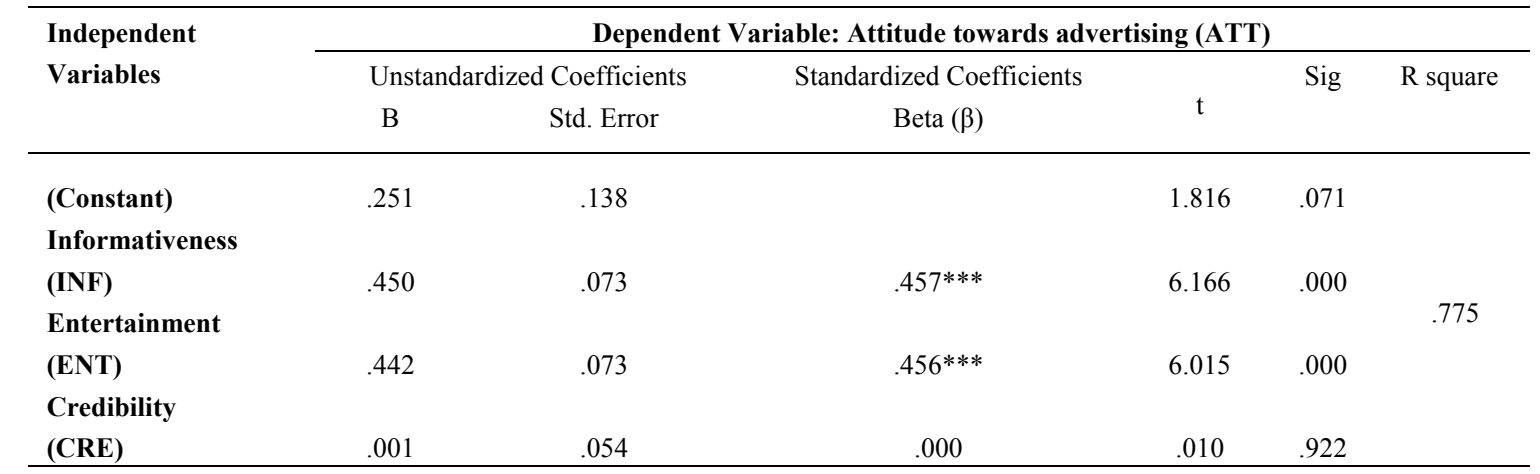

${ }^{*} \mathrm{p}<.05, * * \mathrm{p}<.01, * * * \mathrm{p}<.001 ;$

Regression Equation: ATT $=0.251+0.450(\mathrm{INF})+0.442(\mathrm{ENT})$.

Table 6. Results of multiple regression analysis for female

\begin{tabular}{|c|c|c|c|c|c|c|}
\hline \multirow{3}{*}{$\begin{array}{l}\text { Independent } \\
\text { Variables }\end{array}$} & \multicolumn{6}{|c|}{ Dependent Variable: Attitude towards advertising (ATT) } \\
\hline & \multicolumn{2}{|c|}{ Unstandardized Coefficients } & \multirow{2}{*}{$\begin{array}{c}\text { Standardized Coefficients } \\
\text { Beta }(\beta) \\
\end{array}$} & \multirow{2}{*}{$\mathrm{t}$} & \multirow[t]{2}{*}{ Sig } & \multirow[t]{2}{*}{ R square } \\
\hline & $\mathrm{B}$ & Std. Error & & & & \\
\hline (Constant) & -.036 & .150 & & -.238 & .812 & \\
\hline \multicolumn{7}{|l|}{ Informativeness } \\
\hline (INF) & .333 & .068 & $.286 * * *$ & 4.890 & .000 & \\
\hline Entertainment & & & & & & .698 \\
\hline (ENT) & .358 & .056 & $.368 * * *$ & 6.458 & .000 & \\
\hline \multicolumn{7}{|l|}{ Credibility } \\
\hline (CRE) & .320 & .049 & $.301 * * *$ & 6.493 & .000 & \\
\hline
\end{tabular}

$* \mathrm{p}<.05, * * \mathrm{p}<.01, * * * \mathrm{p}<.001 ;$

Regression Equation: $\mathrm{ATT}=-0.036+0.333(\mathrm{INF})+0.358(\mathrm{ENT})+0.320(\mathrm{CRE})$.

Table 7. Results of multiple regression analysis for both male and female

\begin{tabular}{|c|c|c|c|c|c|c|}
\hline \multirow{3}{*}{$\begin{array}{l}\text { Independent } \\
\text { Variables }\end{array}$} & \multicolumn{6}{|c|}{ Dependent Variable: Attitude towards Advertising (ATT) } \\
\hline & \multicolumn{2}{|c|}{ Unstandardized Coefficients } & \multirow{2}{*}{$\begin{array}{c}\text { Standardized Coefficients } \\
\text { Beta }(\beta)\end{array}$} & \multirow{2}{*}{$\mathrm{t}$} & \multirow[t]{2}{*}{ Sig } & \multirow[t]{2}{*}{ R squar } \\
\hline & $\mathrm{B}$ & Std. Error & & & & \\
\hline (Constant) & .069 & .104 & & 670 & .503 & \\
\hline \multicolumn{7}{|l|}{ Informativeness } \\
\hline (INF) & .385 & .050 & $.360 * * *$ & 7.775 & .000 & \\
\hline Entertainment & & & & & & .719 \\
\hline (ENT) & .394 & .045 & $.405^{* * *}$ & 8.762 & .000 & \\
\hline \multicolumn{7}{|l|}{ Credibility } \\
\hline (CRE) & .184 & .037 & $.173 * * *$ & 4.983 & .000 & \\
\hline
\end{tabular}

${ }^{*} \mathrm{p}<.05, * * \mathrm{p}<.01, * * * \mathrm{p}<.001$.

A multiple linear regression was calculated to predict gender attitude towards Facebook advertising based on informativeness, entertainment, and credibility of advertising. A significant regression equation was found $(\mathrm{F}(3$, $396)=104.460, p<.001)$, with an $R^{2}$ of .719 . 


$$
A T T=0.069+0.385(I N F)+0.394(E N T)+0.184(C R E)
$$

Independent variables are informativeness, entertainment, and credibility. Gender is the moderating variable. All variables are correlated against the dependent variable attitude towards advertising. The result has provided the support for the hypotheses.

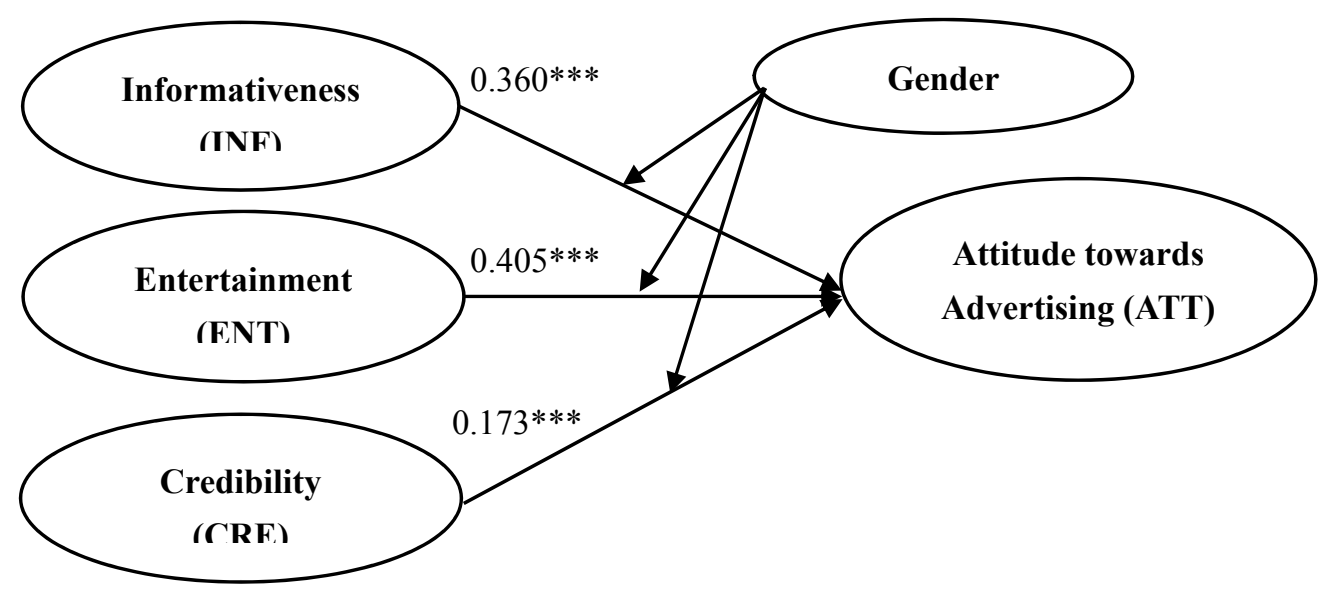

Figure 2. Result of multiple regression analysis on proposed framework

\section{Discussion}

\subsection{Research Findings}

The objective of this study is to investigate the Facebook advertising effectiveness through examining Mongolian users' attitude toward Facebook advertising. This research was designed to answer the following questions:

1) Which factors most affect Mongolian Facebook users' attitude toward Facebook Advertising?

2) Does gender moderate the relationship between Independent Variables (IV) and Dependent Variable (DV)?

\subsubsection{Research Findings for Research Question 1}

Based on Table 7, we can conclude that all hypotheses are accepted. Here are the reasons:

1) Variable Informativeness has an affect into dependent variable Attitude towards Advertising, with numbers Beta $(\beta)=0.360 ; \mathrm{t}=7.775 ; \mathrm{P}$ value $=0.000^{* * *}$. So, $\mathrm{H} 1$ : Informativeness has statistically significant influence on the attitude towards Facebook advertising is accepted.

2) Variable Entertainment has an affect into dependent variable Attitude towards Advertising, with numbers Beta $(\beta)=0.405 ; \mathrm{t}=8.762 ; \mathrm{P}$ value $=0.000^{* * *}$. So, $\mathrm{H} 2$ : Entertainment has statistically significant influence on the attitude towards Facebook advertising is accepted.

3) Variable Credibility has a positive affect into dependent variable Attitude towards Advertising, with numbers Beta $(\beta)=0.173 ; \mathrm{t}=4.983 ; \mathrm{P}$ value $=0.000^{* * *}$. So, H3: Credibility of advertising has statistically significant influence on the attitude towards Facebook advertising is accepted.

4) Gender has statistically significant moderating influence on ATT. Both male and female has Beta ( $\beta$ ) number that is different in the variables INF and ENT, but the difference is of considerable value for the variable CRE. Based on Table 5 and Table 6, for CRE, male shows Beta $(\beta)=0.000 ; \mathrm{t}=0.10 ; \mathrm{P}$ value $=0.922$ and female shows Beta $(\beta)=0.301^{* * *} ; \mathrm{t}=6.493$; $\mathrm{P}$ value $=0.000^{* * *}$. So, it can be concluded that there is significant different attitude between male and female regarding the credibility of advertising. Advertising credibility has been defined by Mackenzie \& Lutz (1989) as the extent to which the consumer perceives claims made about the brand in the ad (advertising) to be truthful and believable. Seemingly male pay no attention to the truthfulness of advertising and female do. For the male FB audience in Mongolia ENT and INF is of more crucial value. Therefore, H4: There are significant differences between male and female Facebook users' attitude toward Facebook advertising is accepted.

Correlation coefficient all of the variables indicated a significant influence on attitude towards advertising for 
both male and female together. Informativeness and Entertainment have stronger positive influence on attitude towards advertising. So marketers advertising on FB to Mongolian FB users should give more attention that their advertisings were more informative and entertaining. All variables chosen in this study proved that they were good indicators to explore Mongolian Facebook users' attitude towards advertising. ENT, INF and CRE account for $72 \%$ of the variation in attitude of FB users towards advertising.

\subsubsection{Research Findings for Research Question 2}

The results of the study indicate that gender moderates the relationship between Independent Variables (INF, ENT and CRE) and Dependent Variable (ATT). Table 6 shows the results for female Mongolian FB users. Based on the results $70 \%$ of the variation on female FB users' attitude toward advertising is influenced by INF, ENT and CRE. The results for the male population indicate that $78 \%$ of the variation on male FB users' attitude toward advertising is influenced by INF and ENT, leaving CRE out of the equation. This indicates the importance of the informativeness and entertainment for male FB users.

For the female FB users in Mongolia ENT is of first importance, followed by CRE and INF. For male FB users in Mongolia INF and ENT are almost equally important, however CRE has no importance. FB advertisers should pay more attention to designing their ads for male and female Mongolian FB users. The importance of INF and ENT for male should of first priority for male FB users. When it comes to female Mongolian FB users, however, the advertisers should pay more attention to CRE of their product.

\subsection{Recommendations for Future Studies}

The limitations and implications discussed point at some areas for further study and research. Regarding the factors that affecting Mongolian Facebook users' attitude towards advertising, further research may contribute to better understanding of the phenomenon. Further studies could carry out to develop and validate the models by adding external constructs to fit Facebook users' attitude towards advertising within a more specific context. In addition, by adding more demographic variables and more participants could make this study more complex.

\section{Conclusion}

Facebook has been using the latest applications and tools in order to: 1) attract users all around the World, 2) explore the factors affecting Facebook users' attitude towards advertising, 3) help marketers to improve and validate their understanding about Facebook users, 4) to satisfy more internet customers and 5) create better engagement with their customers. This study uses survey questionnaire to gain a better understanding of Mongolian Facebook uses.

The paper at hand investigates the influences of traditional factors of advertising on online marketing to gain a better understanding of Mongolian Facebook users' attitudes toward Facebook advertising. More specifically, the effectiveness of Facebook advertising is investigated. The focus of the study is to gain a better understanding of influencing factors on users' perceived advertising value of Facebook marketing. The results show that the internet users' attitude toward advertising via Facebook and advertising value are strongly related to the Informativeness and the Entertaining of the advertising posts via Facebook site. Besides, there is a significant difference of attitude between male and female regarding the Credibility of advertisement. In addition, gender as moderating variable significantly moderates the relationship between Independent Variables (IV) and Dependent Variable (DV).

Most of prior studies strongly suggest that Informativeness, Entertainment, and Credibility were positively affected attitudes towards advertising. The results of this study, with Mongolian Facebook users, support the previous findings.

\section{References}

Acquisti, A., \& Gross, R. (2006). Imagined communities: Awareness, information sharing, and privacy on the Facebook. Journal of Privacy Enhancing Technologies, 36-58.

ADB Report. (2016). Asian Development Outlook. Retrieved from http://www.adb.org/countries/mongolia/economy\#tabs-0-0

ALsamydai, M. J., Yousif, R. O., \& Al-Qirem, I. A. (2013). Measuring individual attitude towards arabic-speaking tv channels and the impact of these channels on current events. International Journal of Business and Management, 8(1), 73-88. http://dx.doi.org/10.5539/ijbm.v8n1p73

Ashmawy, M. E. (2014). Measuring the University Students' Attitude toward Facebook Advertising. (Master Master's Thesis), Arab Academy for Science, Technology and Maritime Transport, Arab Academy for Science, Technology and Maritime Transport. 
Aydin, G. (2016). Attitudes towards digital advertisements: Testing differences between social media ads and mobile ads. International Journal of Research in Business Studies and Management, 3(2), 11.

Bauer, R., \& Greyser, S. (1968). Advertising in America: The Consumer View. Graduate School of Business Administration, Division of Research. Boston: Harvard University.

Boyd, D. (2007). Why youth (heart) social network sites: The role of networked publics in teenage social life. MacArthur Foundation Series on Digital Learning. Journal of Youth, Identity, and DigitalMedia, Volume. Cambridge, MA: MIT.

Boyd, D. (2007). Why Youth (Heart) Social Network Sites: The Role of Networked Publics in Teenage Social Life. Cambridge, MA: MIT Press: MacArthur Foundation Series on Digital Learning.

Brackett, L., \& Carr, B. (2001). Cyberspace advertising vs. other media: Consumer vs mature student attitudes. Journal of Advertising Res., 41(5), 23-32. http://dx.doi.org/10.2501/JAR-41-5-23-32

Deraz, D., Awuah, G. B., \& Gebrekidan, D. A. (2015). Assessing the value of social network sites' advertisements. Proceedings of the Third International Conference on E-Technologies and Business on the Web, 13 .

Ducoffe, R. (1996). Advertising value and advertising on the Web. Journal of Advertising Research, 36(5), 21-21.

Eisend, M., Plagemann, J., \& Sollwedel, J. (2014). Gender roles and humor in advertising: The occurrence of stereotyping in humorous and nonhumorous advertising and its consequences for advertising effectiveness. Journal of Advertising, 43(3), 19. http://dx.doi.org/10.1080/00913367.2013.857621

Eze, U. C., \& Lee, C. H. (2012). Consumers' Attitude towards Advertising. International Journal of Business and Management, 7(13), 15. http://dx.doi.org/10.5539/ijbm.v7n13p94

Facebook Newsroom. (2016). Company info facebook newsroom. Retrieved from http://newsroom.fb.com/company-info/

Facebook Statistics. (2016). Facebook Statistics for fans in Mongolia. Retrieved from $\mathrm{http}: / /$ www.socialbakers.com/statistics/facebook/pages/local/mongolia/

Friman, J. (2010). Consumer Attitudes Toward Mobile Advertising. Finland. Aalto University.

Gao, Y., \& Koufaris, M. (2006). Perceptual antecedents of users attitude in electronic commerce. Journal of Advances in Information Systems, 37(273), 42-50. http://dx.doi.org/10.1145/1161345.1161353

Hanna, N., \& Wozniak, R. (2001). Consumer Behavior: An Applied Approach. In Consumer Attitudes (p. Chapter 6). Prentice Hall: NJ. 174.

Karr, D. (2014). Brief History of Social Media Advertising. Retrieved from https://www.marketingtechblog.com/brief-history-social-media-advertising/

Katherine, K. (2010). Privacy and Perceptions: How Facebook Advertising Affects its Users Strategic. Journal of Undergraduate Research in Communications, 1(1).

Kotler, P. (1988). Marketing Management: Analysis Planning and Control. New Jersey: Prentice Hall.

Krombholz, K., Merkl, D., \& Weippl E. (2012). Fake Identities in Social Media: A Case Study on the Sustainability of the Facebook Business Model. Journal of Service Science Research 4, 175-212. http://dx.doi.org/10.1007/s12927-012-0008-z

Learmonth, M., \& Klaassen, A. (2009). Facebook's plan to ramp up ad revenue. Journal of Advertising Age, $80(4)$.

Lee, C. M., Loo, C. H., Peng, C. S., \& Xian, S. G. (2014). Consumers' attitude towards online advertising: The study on informational responses (Undergraduate Bachelor's Thesis), Universiti Tunku Abdul Rahman, Universiti Tunku Abdul Rahman.

Louise, S. (2007). ADVERTISING/Facebook Is Marketing Your Brand Preferences (With Your Permission). Retrieved from http://www.nytimes.com/2007/11/07/technology/07adco.html

Lutz, R. J. (1985). Affective and cognitive antecedents of attitude toward the ad: A conceptual framework. Psychological Processes and Advertising Effects, 45-63. 
MacKenzie, S., \& Lutz, R. (1989). An empirical examination of the structural antecedents of attitude toward the $\mathrm{ad}$ in an advertising pretesting context. Journal of Marketing, 53(2), 48-65. http://dx.doi.org/10.2307/1251413

McQuail, D. (1983). Mass communication theory: An Introduction. London: Sage Publishing.

Mittal, B. (1994). Public assessment of TV advertising: faint praise and harsh criticism. Journal of Advertising Research, 34(1), 35- 53.

Moore, G. (1991). Crossing the Chasm: Marketing and Selling Technology Products to Mainstream Customers. New York: Journal of Harper Business.

Oh, L., \& Xu, H. (2003). Effects of multimedia on mobile consumer behavior: An empirical study of location-aware advertising. Retrieved August 10, 2013.

Okoe, A. F., \& Boateng, H. (2015). Consumer attitudes toward and intentions to accept mobile advertising. Growing Science, 5, 10. http://dx.doi.org/10.5267/j.msl.2015.7.002

Petty, R., \& Cacioppo, J. (1981). Attitudes and Persuasion: Classic and Contemporary Approaches. Dubuque: IA: A.C. Brown.

Pollay, R., \& Mittal, B. (1993). Here's the beef: Factors, determinants \& segments in consumer criticism of advertising. Journal of Marketing, 57(7), 99-114. http://dx.doi.org/10.2307/1251857

Rehman, F. U., Ilyas, M., Nawaz, T., \& Hyder, S. (2014). How facebook advertising affects buying behavior of young consumers: The moderating role of gender. Academic Research International, 5, 10.

Sachiko, M. (2004). Children and Media. Journal of Young Consumers: Insight and Ideas of Responsible Marketers, 6, 37-43.

Scott, B., MacKenzie, \& Lutz, R. J. (1989). An Empirical Examination of the Structural Antecedents of Attitude toward the $\mathrm{Ad}$ in an Advertising Pretesting Context. Journal of Marketing, 53, 48-65. http://dx.doi.org/10.2307/1251413

Shavitt, S., Lowrey, P., \& Haefner, J. (1998). Public attitudes toward advertising: More favorable than you might think. Journal of Advertising Research, 38(4), 7-12.

Sosor. (2012). Factors influencing the Usage of Mobile Banking in a Mongolian Context. Asia University, 1-90.

Wei, Y. P., \& Long, P. H. (2015). Consumer's perception of mobile social media advertising: The case of casual-dining restaurants. Advances in Information Sciences and Service Sciences, 7(1), 13.

\section{Copyrights}

Copyright for this article is retained by the author(s), with first publication rights granted to the journal.

This is an open-access article distributed under the terms and conditions of the Creative Commons Attribution license (http://creativecommons.org/licenses/by/4.0/). 